\title{
Introduction
}

\section{Dennis Dierks*}

\section{Introduction: Understanding Diverse Uses of Painful Pasts. A Plea for Conscious Normativity}

https://doi.org/10.1515/iph-2022-2030

Keywords: difficult pasts, shared authority, sharing authority, citizen science, conscious normativity

The three case studies of this special section address an issue that is undoubtedly at the core of the ethics of Public History: the quest to democratize history. They approach a problem that has concerned Public History from its very beginnings in the 1970s when, inspired by social and political activism such as the civil rights movement or the student protests of the 1960s in the United States, public historians started to rethink the way historical knowledge is created. ${ }^{1}$ This critical reflection referred to three central points that are still relevant today.

First, the role historiography and other modes of remembrance played in reproducing the grand narratives of Western superiority, race, gender, and bourgeois elitism was critically questioned, for these narrations systematically excluded and devalued the historical experiences of large population groups all around the world. This challenged the discipline which at the time was still under the spell of nineteenth-century models of telling history as the endeavor of the notorious great white men. Black Lives Matter and the ongoing critical reassessment of European colonial history show that this process is far from being concluded.

The second concern is the place of academic history in society and the way professional historians communicated with the broader public. And finally, thirdly, there is the question of how historical knowledge is produced and reproduced. This process has never been completely monopolized by academic scholars or statedriven institutions and - especially with regard to the

1 For a historicization of Public History both as a movement and an academic discipline, see Thomas Cauvin, Public History: A Textbook of Practice (New York: Routledge, 2016), 2-9.

*Corresponding author: Dennis Dierks, Department of History, University of Jena, Jena, Germany, E-mail: dennis.dierks@uni-jena.de implementation of politics of remembrance in everyday life - has always relied on negotiation with local audiences. However, the privileged role of academic historians cannot be overstated. They acted (and still act) as experts, defining the rules of knowledge production and deciding whom to coopt in their community of experts. This privilege was now and is still being questioned by Public History.

This last point touches upon the fundamental issue of how knowledge is generated and shared in a society. The dimensions of this problem become more apparent when we take a step back and integrate into the argument reflections from the sociology of knowledge. Since the late nineteenth century, when sociological self-reflection on the conditions of modernity began, modern societies have been described as being characterized by a growing functional differentiation. This functional differentiation has been the response to an increasingly complex world in which informed action is only possible on the basis of professionalization and expertise. Science, as the German sociologist Niklas Luhmann describes it in his famous 'System Theory,' has become one of these functional systems. ${ }^{2}$ It is this functional system and the habitus ${ }^{3}$ and truth regimes ${ }^{4}$ it reproduces to which Public History usually refers as the ivory tower from which academic historians should descend.

Such considerations from the field of the sociology of knowledge might help us to understand how challenging the quest for democratizing history is. In a complex society, functional differentiation cannot simply be unmade, as it is based on intellectual experiences that, at best, can only be

2 Niklas Luhmann, The Differentiation of Society, trans. Stephen Holmes and Charles Larmore (New York: Columbia University Press, 1982); Niklas Luhmann, Social Systems, trans. John Bednarz, Jr. (Stanford, CA: Stanford University Press, 1995); Niklas Luhmann and Kerstin Behnke, “The Modernity of Science," New German Critique 61, no. 1 (Special Issue on Niklas Luhmann, 1994): 9-23.

3 For the analytical concept of habitus, see Pierre Bourdieu, Distinction: A Social Critique of the Judgement of Taste (Cambridge, M.A.: Harvard University Press, 1984).

4 Michel Foucault, Discipline and Punish: The Birth of the Prison, trans. Alan Sheridan (New York: Vintage Books, 1977). 
partly shared with non-experts, but never fully reproduced by them. This asymmetric power structure between experts and non-experts cannot be completely overcome, unless the asymmetry of experience is overcome. That is, unless non-experts become experts themselves. On the other hand, the problems associated with the process of functional differentiation through professionalization are obvious: as they do not conform to the requirements of being an expert, people who are identified as non-experts are excluded from the process of academic knowledge production.

Besides that, modern societies are knowledge societies, which means that knowledge produced by experts shapes the everyday life of the much broader group of non-experts often in a fundamental way, as the current COVID-19 pandemic drastically shows. At the same time, epistemological constructivism has radically challenged the notion of objectivity in which scientific authority and the authority of experts have traditionally been based. Research, as Thomas S. Kuhn has already argued in his seminal 1962 study "The Structure of Scientific Revolutions," relies on paradigms, on modes how to solve problems that are exposed to temporal change. ${ }^{5}$ What is more, explorations into the sociology of knowledge that are inspired by David Bloor's groundbreaking intervention "Knowledge and Social Imagery" have demonstrated that scientific argumentation is always locationbound. ${ }^{6}$ That is, it depends - to variant degrees - on individual biographical experiences, normative worldviews, and extra-scientific goals pursued by academics when participating in scientific discourse. This also has been eloquently shown for the case of academic history. ${ }^{7}$

All these are sensible reasons to question the monopoly of experts in the field of knowledge production and to remind them of their social responsibility toward the group of non-experts. With regard to history, there is still another important argument: scholars reflecting on the anthropological dimensions of historical thinking have argued that the quest for historical orientation is not limited to those dealing professionally with the past. They helped to create an awareness that all people are historical beings creating "a meaningful relation with the past" 8 and looking for orientation in time. This is echoed by Jerome de Groot's

5 Thomas S. Kuhn, The Structure of Scientific Revolutions (Chicago: University of Chicago Press, 1962).

6 David Bloor, Knowledge and Social Imagery (London: Routledge \& Paul, 1976).

7 Chris Lorenz, "Historical Knowledge and Historical Reality: A Plea for 'Internal Realism',” History and Theory 33, no. 3 (1994): 297-327. 8 Jörn Rüsen, Evidence and Meaning: A Theory of Historical Studies (New York: Berghahn Books, 2017), 13. assessment that every person has a more or less developed understanding of what the past means to him or her, which history is or shall be, which results in different forms of individual and collective engagement with history as well as the existence of markets on which diverse imaginings of the past are traded and consumed. ${ }^{9}$

While sound reasons can be given as to why, in a democratic and self-reflecting society, experts should be aware of their civic responsibilities and show respect for the needs, experiences, and competences of non-experts, exploring fields of collaboration between experts and nonexperts still represents a major challenge. In science this has been discussed under the label of citizen science. ${ }^{10}$ Within the conceptual body of Public History, participatory approaches are usually addressed as sharing or shared authority, which both reflects the concepts of academic citizens (i.e. academic professionals dedicated to community engagement) and citizen scientists (i.e. people from the general public engaging in scientific work, often collaborating with academic scientists). ${ }^{11}$ Textbooks on Public History point to the potential of the involvement of participants from outside the academy, as "multiple voices enhance the diversity in historical narratives,"12 but at the same time emphasize that the generally accepted standards of scientific knowledge production must also apply in such constellations. This is described as the particular challenge of producing historical knowledge by sharing authority. ${ }^{13}$

The contributions of this special section aim at understanding these challenges from an empirical point of view. With the memory of painful experiences of the past, they focus on an issue where approaches associated with shared authority are of particular importance since they can empower victims to speak for themselves and give

9 Jerome de Groot, Consuming History: Historians and Heritage in Contemporary Popular Culture (London: Routledge, 2009).

10 For the ongoing discussion on this approach see the journal Citizen Science: Theory and Practice that has been published by the Citizen Science Association since 2016; for a conceptualization of Public History as citizen science, see Cord Arendes, "Historiker als 'Mittler zwischen den Welten'? Produktion, Vermittlung und Rezeption historischen Wissens im Zeichen von Citizen Science und Open Science," Heidelberger Jahrbücher Online 2 (2017): 19-58. doi: 10.17885/heiup.hdjbo.2017.23691.

11 See the definitions of "citizen science" and "citizen scientist" in the Oxford English Dictionary, https://www.oed.com/, accessed November 23, 2021.

12 Cauvin, Public History, 216.

13 Cauvin, Public History, 216-29; David Dean, "Introduction," in A Companion to Public History, ed. David Dean (Hoboken, NJ: Wiley Blackwell, 2018), 1-11; Cherstin M. Lyon, Elizabeth M. Nix, and Rebecca K. Shrum, Introduction to Public History: Interpreting the Past, Engaging Audiences (Lanham: Rowman and Littlefield, 2017), 1-19. 
silenced memories new voice. Beyond that, dealing with the living memories of violence and war requires a profound sensitivity, which can only be developed in empathetic conversation with the victims themselves.

First drafts of the contributions were presented at a conference ${ }^{14}$ organized by the Jean Monnet Network for Applied European Contemporary History. A central goal of this network project, which was funded by the European Union, was to appreciate and understand the diversity of Public History practices within European societies faced with addressing painful pasts. ${ }^{15}$ The question of how historical knowledge is produced was at the center of its considerations. With its openness to both interdisciplinary and transnational approaches, the network brought together practitioners and scholars from Bosnia-Herzegovina, Belgium, Germany, Poland, Serbia and other parts of Europe and the world with backgrounds in history, political science, cultural studies, as well as social and cultural anthropology. ${ }^{16}$

The network's interdisciplinary approach is also reflected in this special section. Its contributions tackle the question of democratizing history from different angles by analyzing examples in recent history and the present. Focusing on the work of the committee of inquiry set up by the Belgian Parliament to investigate the involvement of Belgian politics in the murder of Patrice Lumumba (1925-61), Georgi Verbeeck's case study is concerned with the complex interplay between social expectations, the politics of the past, and academic historiography. Verbeeck shows how engaged historiography and the public debate it provoked created a social climate in which calls were made for a critical reappraisal of Belgium's long-suppressed violent colonial past. The change of

14 "Public and Applied History on the Battlefield of Europe. Dealing with Painful Pasts in the 20th Century. First conference of the Jean Monnet Network 'Applied European Contemporary History'," H-SozKult, accessed November 17, 2021, www.hsozkult.de/event/id/event84166. I would like to thank Juliane Tomann, the co-organizer of this conference, and all the other network members who contributed to the success of this event: Jörg Ganzenmüller and Željana Tunić from the University of Jena as well as Damir Arsenijević, Judith Brand, Radovan Cukić, Gita Deneckere, Jelena Đorđević, Chantal Kesteloot, Dominik Kretschmann, Judith Mayer, Miloš Ničić, Ljubinka Petrović-Ziemer, Ada Vlajić, Jochen Voit, and Joanna Wojdon.

15 The network was funded by a grant from the European Union's Education, Audiovisual and Culture Executive Agency (EACEA) and part of the Jean Monnet Activities (Grant decision no. 2016-2422, project number 575165-EPP-1-2016-1-DE-EPPJMO-NETWORK).

16 For a documentation of the network activities and its approach, see its webpage: “Applied European Contemporary History,” Applied European Contemporary History, accessed November 17, 2021, https://aec-history.uni-jena.de. government in 1999 generated the conditions for these demands to be taken up by the new center-left majority. Even though the newly established commission of historians demonstrated Belgium's problematic role in the Congo, due to a lack of written evidence it refrained from naming perpetrators within the political elite and the Belgian royal family. However, this was precisely what large parts of the public expected the commission to do. These diverging expectations attest to, Verbeeck argues, "the precarious role of the historian as mediator between academic scholarship and the wider public."

Presenting a local history study, Soňa Mikulová's contribution shows how memory activism coming from outside impacted WWII remembrance in a Bavarian village. Mittenwald, where a monumental memorial of WWI and WWII was erected in 1957, became the home of an annual commemoration for fallen soldiers of the Mountain Troops during which veterans of the Second World War, members of the German armed forces, representatives of the Bavarian government, and local politicians took part. In 2002, activists launched a campaign to draw attention to the silenced war crimes the Mountain Troops had committed in Italy and Southeastern Europe during WWII. Their activism was met with considerable resistance within the local community. After more than seven years of campaigning, the activists succeeded in getting the community to agree that a memorial to the victims, which the activists had erected and which had been removed, would be re-erected. However, this success was only due to pressure from outside, when German and international media began to report on the case. Despite the obvious success of this grassroots movement, Mikulová wonders whether it can be described as a democratization of commemorative practices in the sense of shared authority.

The starting point of Kamila Baraniecka-Olszewska's contribution are Gavriel Rosenfeld's reflections on the normalization of the remembrance of Nazism. With Rosenfeld, she sees normalization as a shift of moral assessments, which ultimately leads to banalization, indifference, and social oblivion. Baraniecka-Olszewska understands this normalization as resulting from a pluralization of actors in remembrance culture. She investigates the consequences of this democratization process for a highly ambiguous example: reenactments of WWII battles in Poland during which Polish reenactors adopt the role of Wehrmacht soldiers and members of the Waffen-SS. Her contribution shows that the reenactors not only see themselves as promoters of expert knowledge generated by the experience of reenactment (especially with regard to technical aspects of war), but that they also believe themselves to be raising awareness of the war's often ignored individual human 
experiences. This belief is rooted in the extensive biographical research typically performed by reenactors before embodying the role of German soldiers, a practice which often leads them to understand Wehrmacht personnel as "normal people" who were forced to go to war. However, what might sound like an attempt to contribute to a differentiated understanding of violence and war is called into question by the behavior of the reenactors themselves as some show a disturbing fascination with national socialist aesthetics, which gives rise to serious doubts about their political attitude and their real motives when taking part in these reenactments.

The comparative analysis of the constellations examined in the contributions allows some conclusions beyond the topical horizon of the case studies, which once again attests to the potential of comparative approaches when analyzing Public History practices. ${ }^{17}$ While in all case studies the democratization of history manifests as a pluralization of actors involved in the process of producing, disseminating, and representing historical knowledge, the circumstances and results of this process differ. Comparing the results of the case studies used by Georgi Verbeeck and Soňa Mikulová shows that in the negotiation processes they investigate, transnational entanglements only played a minor role. This is surprising since in both cases (Belgium's colonial past and the war atrocities of the Wehrmacht), such transnational dimensions do exist in manifold ways. However, in the Belgian case, it was the deliberate decision of the new government to focus exclusively on their country's involvement in the murder of Patrice Lumumba and to ignore other dimensions. In Mikulová's case study, this is due to the way the activists decided to communicate with the local audience. Despite the fact that survivors from the countries occupied during WWII were able to share stories about the atrocities they experienced thanks to the mobilization efforts of the activists, Mittenwald's community members opted not to hear these stories, emphasizing the humiliation resulting from the campaigns against the memorialization of Mountain Troops. In both cases, this led to a focus on the domestic dimensions of the conflict on remembrance, which significantly limited the plurality and diversity of

17 As a plea for comparative approaches, see Serge Noiret and Thomas Cauvin, "Internationalizing Public History," in The Oxford Handbook of Public History, eds. Paula Hamilton and James B. Gardner (New York: Oxford University Press, 2017), 25-43; Paul Ashton and Alex Trapeznik, eds., What is Public History Globally? Working with the Past in the Present (London: Bloomsbury Academic, 2019). the voices that were heard in the respective disputes. Divergent emotional dispositions played a crucial role in this context. They were an important reason for whether historical experiences were taken seriously by the other side or perceived at all, as Mikulová shows in her contribution.

A second, perhaps even more essential point concerns the role of normative assessments, which is particularly evident in the case studies done by Mikulová and Baraniecka-Olszewska. In Mikulová's case, the normative claim of the activists to implement in the public what they considered to be the correct interpretation of the past determined the limits of their willingness to communicate. The local forms of remembrance in the Mittenwald community were perceived as scandalous, and the local protagonists' ability to make a positive change was viewed skeptically. A dialogue with the local population should only take place on the terms of the activists. The memory activists, Mikulová concludes, "shared authority, but only with those with whom they felt solidarity." Normative considerations also play a role in the evaluation of the reenactments analyzed by Baraniecka-Olszewska. To what extent can a society bear pluralizing perspectives on the past? And when does the civic responsibility of public historians urge them to intervene? Reflecting on these questions is imperative when it comes to dealing with painful historical experiences. Here, it is not only important to respect the feelings of victim groups and their descendants; questions also arise regarding the extent to which interpretations of the past can be tolerated when these touch upon the normative foundations of a democratic society. The relativization of the German guilt for the violent crimes of WWII, as it seems to be suggested by at least some of the reenactors investigated by Baraniecka-Olszewska, is clearly unbearable.

As the empirical findings of the case studies presented here show, the reflection on the normative dimensions of historical judgment is of crucial importance for Public History. An in-depth discussion, especially a transnational dialogue like the one this special section aims to stimulate, would be highly compatible with recent debates in the social sciences, where this question is discussed as conscious normativity. ${ }^{18}$

18 Rubén Flores and Ryan Burg, "A Case for Conscious Normativity: Or How Ethics Literacy Can Benefit Sociology Students and Their Teachers," Civic Sociology 2, no. 1 (February 2021). doi: 10.1525/cs.2021. 18219. 